\title{
RESPOSTAS ECOLÓGICAS DAS POPULAÇÕES DE CAMARÕES PALAEMONIDAE A VARIAÇÃO DE FATORES ABIÓTICOS EM UM RESERVATÓRIO DO SEMIÁRIDO NORDESTINO
}

\author{
Lucena, I.C. ${ }^{1,}$; Pinheiro, A.P. ${ }^{2}$; Nascimento, W.M. ${ }^{2}$; Lima, L. S. ${ }^{2}$; \\ Alencar, D.R. ${ }^{2}$; Silva, A.L.L. ${ }^{2}$; Correia, D.B. ${ }^{2} \&$ Cascon, P. ${ }^{1}$ \\ ${ }^{1}$ Universidade Federal do Ceará (UFC), Campus Pici, Laboratório de Zoologia Experimental. \\ ${ }^{2}$ Universidade Regional do Cariri (URCA), Campus Pimenta. Laboratório de Crustáceos do Semiárido. \\ *Autor correspondente: isislucena@gmail.com
}

\begin{abstract}
A variação sazonal da biota aquática geralmente é atribuída à variabilidade ambiental, porém esta relação não é clara em reservatórios, visto que são ecossistemas artificiais altamente dinâmicos ao longo do tempo. O objetivo do presente estudo foi o de analisar a possível influência das variáveis ambientais (pluviosidade, profundidade, temperatura, oxigênio dissolvido, $\mathrm{pH}$, amônia, sólidos totais dissolvidos e condutividade elétrica) nas populações de camarões palaemonídeos em um reservatório do semiárido nordestino, amostrado durante os períodos seco e chuvoso (outubro/2016 a setembro/2017). As coletas foram realizadas no reservatório do Rosário (653'17.3"S, 3904'39.9”W), localizado na bacia hidrográfica do Rio Salgado, afluente da bacia do Rio Jaguaribe na região sul do estado do Ceará. Trinta áreas amostrais foram marcadas na região litorânea do reservatório, equidistantes 300 metros entre si. Em cada área, foram dispostos cinco transectos perpendiculares à margem do reservatório, alinhados paralelamente e distantes $10 \mathrm{~m}$ entre si, partindo da zona litorânea até a zona limnética na coluna d'água. Para cada transecto, as medidas abióticas e amostras biológicas foram replicadas em intervalos de cinco metros em direção às áreas mais profundas. Os camarões foram coletados em meio à vegetação litorânea do reservatório, com o uso de peneiras (diâmetro $50 \mathrm{~cm}$; malha entre nós $2 \mathrm{~mm}$ ) por toda extensão de cada transecto. Destes, 3.398 (80,92\%) foram da espécie Macrobrachium amazonicum e 801 (19.08\%) da espécie Macrobrachium jelskii. Para investigar a influência dos fatores abióticos amostrados sobre a abundância das espécies de camarões, foi realizada uma análise de redundância (ARD) para cada período. As populações de camarões foram mais abundantes no período seco em comparação com o período chuvoso, e a espécie Macrobrachium amazonicum foi mais abundante que Macrobrachium jelskii em ambos os períodos. No geral, foram evidentes as diferenças dos fatores abióticos específicos para cada espécie de camarão, entretanto, a variação sazonal dos fatores abióticos não foi suficiente para explicar à abundância delas nesse reservatório.
\end{abstract}

Palavras-chave: Decapoda, abundância, Macrobrachium amazonicum, Macrobrachium jelskii, Caatinga Médio-Nordeste. 